\title{
Tráfico artístico cortesano: El paso franco de obras de arte por el Reino de Aragón en el siglo XVII
}

\author{
Artistic traffic at the Spanish court: The free passage of works of \\ art through the kingdom of Aragón in the $17^{\text {th }}$ century \\ Rubén LÓPEZ CONDE \\ Universidad de Jaén
}

Recibido: 30-IX-2016

Aceptado: 5-V-2017

RESUMEN: El examen de los pasaportes expedidos durante el siglo XVII por el Consejo de Aragón nos ha permitido conocer el envío o tránsito por el país de un buen número de piezas artísticas remitidas por o destinadas a la corte madrileña. La mayoría de los documentos reunidos refiere envíos que atañen a los sitios y palacios del rey, al coleccionismo cortesano y al trasegar de obras de arte pertenecientes a personajes principales de la política de su tiempo. Solo unos pocos registros afectan a remesas ya consignadas en las cédulas de paso de la Cámara de Castilla -las únicas que hasta ahora se habían estudiado en profundidad-, si bien la información transmitida no siempre es la misma, siendo así que, en ocasiones, la documentación aragonesa avanza e incluso enmienda los datos aportados por la castellana.

Palabras clave: Sitios Reales, Felipe IV, Presentes, Pasaportes, Cédulas de paso

ABSTRACT: The examination of the passports issued in the seventeenth century by the Council of Aragon has allowed us to find about the shipping and the traffic through Spain of a great number of works of art which were sent from or adressed to the court in Madrid. Most of the collected documents concern shipments related to the King's sites and palaces, the courtly collecting and the movement of artworks belonging to the main political figures of the time. Only a few records refer to shipments already recorded in the passage licenses (cédulas de paso) of the Chamber of Castile-the only that had hitherto been studied in depth-, although the information is not always identical, since the documentation of the Council of Aragón advances and even amends the data provided in Castilian documentation.

Key words: Royal Sites, Philip IV, Gifts, Passports, Passage licenses

\section{ESTADO DE LA CUESTIÓN}

Invocar la riqueza documental de los llamados libros de passo es algo que hoy se nos plantea innecesario. Hace ya casi un cuarto siglo que Morán Turina y Karl Rudolf recuperaron para la Historia del Arte los valiosísimos documentos con que se toparon en el transcurso de sus investigaciones en los Archivos de Simancas e Histórico Nacional1:

\footnotetext{
1 En dos trabajos que hoy podemos considerar referenciales: J. M. MORÁN TURINA y K. RUDOLF, "Nuevos documentos en torno a Velázquez y a las colecciones reales", Archivo Español de Arte, 259260, 1992, pp. 289-302 y J. M. MORÁN TURINA,
} 
documentos que aludían a Velázquez y otros importantes artistas, a la retratística regia, a presentes y empresas artísticas de primera magnitud, al trashumar de obras de arte por las diferentes cortes europeas, al coleccionismo de un sinnúmero de figuras relevantes de la época en comunicación directa con la monarquía española; información extraída, las más de las veces, de las cédulas de paso dispensadas a lo largo del siglo XVII por la Cámara de Castilla.

Cribando de entre esta vastísima documentación la información relativa a las "licencias concedidas a obras de arte adquiridas o regaladas por o para la Corona y a bienes de embajadores españoles y extranjeros, militares y funcionarios que abandonaban Castilla para ocupar determinados puestos al servicio de la monarquía o que una vez terminada su misión regresaban a la corte" ${ }^{\prime 2}$,

"Importaciones y exportaciones de pinturas en el siglo XVII a través de los registros de los libros de pasos", en Madrid en el contexto de lo hispánico desde la época de los descubrimientos. Actas del Congreso nacional, Madrid, 1994, pp. 543-562. Véanse también las investigaciones que, a sugerencia del propio Morán y sobre la base de una amplísima documentación, desarrollaron A. PÉREZ DE TUDELA y A. JORDAN, “Luxury Goods for Royal Collectors: exotica, princely gifts and rare animals exchanged between the Iberian Courts and Central Europe in the Renaissance (1560-1612)", Jahrbuch des Kunsthistorischen Museums Wien, 3, 2001, pp. 1-127; los siempre fecundos estudios del profesor B. J. GARCÍA GARCÍA, "Los regalos de Isabel Clara Eugenia y la Corte española. Intimidad, gusto y devoción", Reales Sitios, 143, 2000, pp. 16-27, "El legado de arte y objetos suntuarios de las testamentarías de Isabel Clara Eugenia y el Cardenal Infante (1634-1645)", en J. L. COLOMER (ed.), Arte y diplomacia de la monarquía hispánica en el siglo XVII, Madrid, 2003, pp. 134-159 y "Regalos diplomáticos y bienes suntuarios en la corte española (1580-1665)", en E. GARCÍA SANTO-TOMÁS (ed.), Materia crítica: Formas de ocio y de consumo en la cultura áurea, MadridFrankfurt, 2009, pp. 213-249; la interesante aportación realizada por S. TORRÁS, Pintura catalana del barroc. L'auge col-leccionista $i$ l'ofici de pintor al segle XVII, Barcelona, 2012, pp. 206-226; o el decepcionante (por la discrepancia entre expectativas y resultados) trabajo inaugural de A. ALVAR EZQUERRA, “Los intercambios culturales entre los Países Bajos y Castilla en tiempos de Felipe II. Un muestreo de las cédulas de paso", Indagación. Revista de Historia y Arte, 2, 1991, pp. 91-110.

${ }^{2}$ J. M. MORÁN TURINA, Op. cit., p. 544. llegaron a obtener datos muy precisos a propósito de algunos celebrados retratos ejecutados por Velázquez y/o su taller (entre otros, el del infante Baltasar Carlos, el de la infanta Margarita o el de la reina Mariana de Austria, todos en el Kunsthistorisches Museum de Viena) o sobre el arribo a nuestro país de algunas conocidas obras (caso del Crucificado de Domenico Guidi, La Visitación de Rafael o parte de los paisajes con ermitaños comisionados en Italia por Felipe IV para decoración del Retiro); les permitió asimismo delimitar un pequeño conjunto de coleccionistas foráneos presumiblemente interesados en nuestro arte y que a la sazón enriquecieron sus colecciones con piezas locales; establecer los tiempos de algunas empresas artísticas y decorativas de gran envergadura; precisar la intervención de algunos funcionarios y agentes españoles implicados en las mismas (caso del marqués de Castel Rodrigo y los citados paisajes de ermitaños; de Velázquez y algunas de las piezas adquiridas durante su segundo soggiorno italiano; de los cinco caxones de pinturas remitidas por el almirante de Castilla; o del envío a Florencia del retrato y modelo de Felipe IV, consabidas obras de Velázquez y Montañés que habrían de servir a la elaboración de la estatua de Tacca); dar cuenta de la intensidad o el volumen de los intercambios artísticos habidos entre cortes; o adelantar en el conocimiento de las colecciones atesoradas por algunos próceres españoles. En resumen, aquellos documentos permitían ponderar el intenso tráfico artístico establecido entre las altas esferas de la política europea en el siglo XVII y verter datos concretos sobre obras, artistas, comitentes y coleccionistas. Y solo por citar algunas de sus aportaciones más relevantes ${ }^{3}$.

\footnotetext{
${ }^{3}$ Tomando por base las cédulas de paso otorgadas por la Cámara de Castilla, los estudios de Pérez de Tudela y Jordan se centraron en el intercambio de regalos entre las diferentes ramas de los Habsburgo durante la segunda mitad del XVI y principios del XVII. Los de Bernardo J. García se circunscribieron, con felices resultados, a las relaciones entre las cortes española y flamenca (1598-1634) y al examen de la figura y el legado artístico de Isabel Clara Eugenia, ahondando en un ulterior y completísimo trabajo en la cultura
} 
Con todo y ser valiosísima esta documentación, su propio carácter, como señalaba Morán Turina, imponía ciertas limitaciones al estudio: por un lado, muchas de las obras arribadas a España no quedaron consignadas en los citados libros de paso (o no se ha conservado memoria o no se procedió a su registro); y por otro, la referencia a quadros e imájenes -a diferencia de otros objetos suntuarios, prolijamente descritos- resultaba en exceso lacónica, al menos, con carácter general, apareciendo sencillamente registradas como tales, sin mención alguna a su autoría ${ }^{4}$, iconografía e, incluso, en no pocas ocasiones, su específico número ("diferentes láminas y pinturas", "quatro caxas de pinturas", "una caja larga con lienços de pintura"...). Nosotros añadimos una más: la serie documental rastreada se ceñía exclusivamente a Castilla y su Cámara (y no todos los envíos o recámaras debían pasar forzosamente por este reino ${ }^{5}$ o se dirigían a Madrid, amén de que la Cámara no fue el único órgano del sistema polisinodial que emitió documentos similares). Y es aquí que se impone un examen similar para las licencias o exenciones concedidas al paso de mercancías por el otro gran reino peninsular, Aragón, que si bien adolece de las mismas limitaciones manifestadas para el castellano (si no más), ayuda a completar el trabajo realizado por los citados investigadores, ratificando, enmendando e incluso suministrando nuevos datos e informaciones sobre el tráfico artístico habido en España durante el siglo XVII.

material y el coleccionismo cortesano en el siglo XVII a través del examen de las cédulas de paso emitidas entre 1580 y 1665 . Por su parte, Santi Torrás -sin un ánimo exhaustivo y lejos de nuestros propósitos- dio a conocer algunos relevantes pasaportes otorgados por la Generalitat catalana durante el siglo XVII. A todos estos trabajos nos hemos referido en la primera nota.

${ }^{4}$ En la documentación castellana solo se explicitaban dos nombres, Ribera y Rafael: J. M. MORÁN TURINA, Op. cit., p. 545.

${ }^{5}$ Caso de los virreyes y otros altos funcionarios que no partían de Madrid (o no lo hacían sus recámaras), sino de sus propios feudos o estados, o de la aristocracia italiana que sirvió en Navarra, Cataluña, Aragón o Valencia.

\section{LAS GENERALIDADES}

De cédulas de paso a pasaportes; de alcabalas, portazgos y otros impuestos que gravaban el transito o peaje de mercancías por Castilla a las generalidades de Aragón. Los documentos y fórmulas también cambian. No se conserva, como en el caso de Castilla, un registro compacto y sistemático de las exenciones dadas a las ropas, joyas y alhajas de paso por el reino aragonés. Para dar con estos pasaportes (y con las muy estimables memorias que los acompañaban) es preciso bucear por entre los incontables documentos relativos a disposiciones, acuerdos, litigios, cobros, embargos, exenciones, contadurías, balances y otras materias relativas a los derechos del general o generalidades, un impuesto que gravaba la entrada y salida de cualesquiera géneros y mercaderías por el territorio de Aragón, y cuya administración, recaudación y arriendo corría a cargo de la Diputación del Reino, organismo foral con amplias competencias en materia fiscal ${ }^{6}$.

Entre los muchos y muy diferentes negocios que conforman este bloque documental, conservado en el Archivo de la Corona de Aragón, sección Consejo de Aragón7, es posible encontrar papeles relativos a la conducta de caudales, a la provisión de bastimentos, municiones y pertrechos para la guerra, a la introducción y saca de caballerías y otras bestias de carga y tiro, al abasto de Aragón y demás reinos peninsulares, a la importación y exportación de materias primas y productos elaborados, a la penetración de objetos suntuarios, a las obligaciones y franquezas de los asentistas o, lo que es más importante

${ }^{6}$ Sobre el funcionamiento de esta institución: J. A. SESMA, "Las Generalidades del Reino de Aragón: su organización a mediados del siglo $\mathrm{XV}^{\prime \prime}$, Anuario de historia del derecho español, 46, 1976, pp. 393-468 y A. CANELLAS, "Instituciones aragonesas de antaño. La Diputación del Reino", Cuadernos de Historia Jerónimo Zurita, 33-34, 1979, pp. 7-30.

7 Son muchos los legajos revisados para la elaboración del presente trabajo, si bien solo resultan útiles a nuestros intereses los siguientes: Archivo de la Corona de Aragón (en adelanta ACA), Consejo de Aragón, Legajos 53/3, 54, 55 y 58. 
para este trabajo, al paso franco de los envíos y bagajes de príncipes, embajadores, militares, virreyes y otros ministros de la monarquía.

Aunque teóricamente este impuesto recaía sobre todo aquel -generalidad- que introducía o extraía mercancías del reino de Aragón, sin distinción ni privilegio alguno (a excepción del monarca y de sus más inmediatos familiares, siempre que fueran con el rey o acompañaran sus equipajes), en la práctica, y por razón de una excepcionalidad convertida, a fuer de reiterarse, en costumbre -avalada, por todo lo demás, por la siempre incontrovertible discrecionalidad del monarca- y el creciente desarrollo de la práctica diplomática-que imponía no solo la inviolabilidad del equipaje de los ministros públicos, sino también la más elemental deferencia para con los visitantes, a quienes no debía hacerse vejación ni molestia alguna9-, fueron muchos los eximidos del pago de este arancel. Poco a poco, los pasaportes participados por el soberano fueron multiplicándose, llegando a alcanzar -pese a las repetidas protestas de diputados y arrendadores, que invocaban los muchos actos de Corte en

\footnotetext{
${ }^{8}$ Múltiples son los actos de Corte que apuntan en esta línea y múltiples las protestas y memoriales elevados al rey por los diputados y arrendadores del general, que invocaban repetidamente el abuso con que se empleaba esta regalía. Cfr. Ibídem Legajo 55, Documento 12; Legajo 58, Documento 81; o Legajo 59, Documento 28.

${ }^{9}$ Sirva de botón de muestra la queja elevada al rey por el nuncio Visconti Borromeo, arribado a España en misión extraordinaria en 1659, "por las vexaciones que se le hizieron en Çaragoça por el arrendador [...] que quiso cobrar a título de derechos 311 Reales de platta [...] sin dar credito a las memorias [...] abrieron los fardos, y lo reconocieron todo manuseandolo con poca atençion y rispeto [...] como esto mira a la inmunidad que de derecho de las gentes gozan [...] los Ministros de Principes [...] parece necesario el remedio a este incombeniente para que no passe en ejemplar una tan mala introduccion, y este lo espera el Nuncio de la Real Grandeza de Vuestra Majestad mediante la restitución de lo [...] cobrado, y algun castigo al atrevemiento y descortesia de el mismo". Ibídem Legajo 55, Documento 166-167. Cfr. asimismo B. J. GARCÍA GARCÍA, "Regalos diplomáticos y bienes suntuarios...", pp. 222-223.
}

contrario, cuando no los fraudes que estas exenciones podían aparejar: la introducción o extracción clandestina de mercaderías no declaradas ${ }^{10}$ - a todo envío o recámara que transitara por Aragón y cupiera en las fórmulas: "por ser cosas que me son propias" o "para mi servicio" o pertenecer a aquellos que "van a servirme" o "vienen por negocios de Su Majestad" (amén de otras análogas), lo que facultaba el pasaje de cuantas remesas llegaban o partían de la corte, de cuantos acudían o volvían de servir al rey en provincias $\mathrm{y}$, con alguna enmienda o adición, de cuantos extranjeros entraban o salían en cumplimiento de misiones diplomáticas.

Para evitar fraudes, los despachos de franqueza extendidos por el Consejo en nombre del rey se hacían acompañar de memorias que daban cuenta con mayor o menor prolijidad de las ropas, joyas y alhajas transportadas o enviadas por el eximido (cuyos bultos, fardos y líos se verían indefectiblemente sometidos a la inspección de los collidores). Y es precisamente este documento el que, pese a ciertas limitaciones, aquí nos interesa ${ }^{11}$. Unas memorias que desafortunadamente no siempre se hallan entre los papeles conservados (cabe pensar que fueran estas las que por premura o indolente pragmatismo se presentasen en las collidas o puntos de recaudación). De entre las que sí nos han llegado, muchas son las que refieren únicamente el número de cajas, arcas, fardos y líos, sin especificación de contenido o vagas alusiones al mismo; otras sencillamente recogen el importe estimado de las joyas y ropas portadas por el beneficiado, la clase y el número de sus monturas y la suma de dinero habida consigo. Por el contrario, también las hay que ni siquiera olvidan referir los lienzos para narices. Las redactadas al detalle relacionan servicio de cocina y alimentos; tocador y perfumería; vestido y

${ }^{10}$ ACA, Consejo de Aragón, Legajo 55, Documento 123 y Legajo 60/1, Documento 1-3.

${ }^{11}$ Aun cuando en ocasiones las órdenes despachadas por el rey dieran pistas o hicieran mención explícita al contenido. 
ropa blanca; textiles, muebles, joyas y otras alhajas; carros, monturas, sillas, gualdrapas, jaeces y otros aderezos de caballería; armas blancas y de fuego y sus respectivos adornos y envolturas; y aún explicitan el metálico portado por el principal y sus criados. Innúmeras son las piezas de platería y joyería inventariadas (descritas casi siempre en pormenor y valuadas), como innúmeros los textiles para el aderezo de una estancia o vivienda (tapicerías, colgaduras, paños, reposteros, antepuertas, sobrepuertas, cortinas, cubiertas, tapetes), piezas en todo caso de equívoca suerte y distinción, por cuanto apenas se precisa su tejido, en ocasiones su tamaño y guarnición y rara vez su representación; y huelga decir que no siempre se emplearía una terminología unívoca o precisa. Por lo demás, y también ocasionalmente, se distingue entre mercancías nuevas o adquiridas y viejas o usadas; circunstancia esta que nos permite determinar, sin atisbo de duda, las piezas adquiridas en nuestro país -en el caso de las memorias que refieren la salida de visitantes extranjeros- o fuera del mismo -para cuantos regresan a tierras de España-. De entre las cosas que se descubren en las relaciones inclusas y que se saben o intuyen de procedencia española cabe referir: cordobanes y guadamecíes, hojas de espada, pomas y pastillas de olor, abanicos, rosarios, cruces, medallas y medidas de devoción, faltriqueras, guantes de ámbar, paños negros y de colores, de tafetán y de Segovia, objetos obrados con materiales de Indias, chocolate y tabaco, botones y cadenas de oro. Constan asimismo las joyas y cintillos de diamantes con que la Corona solía obsequiar a los legados extranjeros al final de sus embajadas ${ }^{12} y$

${ }^{12}$ Sirva de ejemplo la joya que el rey entregó al modenés Fulvio Testi en 1639: "un cintillo de diamantes de oro pulido que tiene sesenta y ocho tachones con tres diamantes cada uno[,] el uno jaquelado y los dos pequeños tablas, y cavo[,] evilla y pasador que en todos son ciento y tres diamantes los veinte y cinco jaquelados y los demas fondos, y una sortija de oro pulido que tiene siete diamantes quatro fondos y tres rosas": ACA, Consejo de Aragón, Legajo 53/3, Documento 100. Cabe llamar la atención sobre el alto valor político y simbólico que adquieren algunas de estas lujosas las ayudas de costa otorgadas por cortesía de Su Majestad. Destaca también la abundancia de piedras bezoares recogidas en las memorias, que, junto con los objetos de caparazón de tortuga, cuerno de bada (rinoceronte) y unicornio (narval), e incluso piezas tan sorprendentes como la piel y las uñas de la gran bestia (tapir americano), remiten al mundo mágico-prodigioso de las Wunderkammer ${ }^{13}$.

\section{CONVERGENCIAS Y DIVERGEN- CIAS}

Vista en conjunto, no resulta fácil ordenar la variopinta información extraída de los casi setenta pasaportes aquí considerados. Pocos son -apenas unos quince- los que retoman entradas ya consignadas por Rudolf y Morán Turina ${ }^{14}$. Sin embargo, aun cuando

piezas, caso de las medallas traídas por algunos funcionarios centroeuropeos con el retrato de un rey español ya difunto, y que constituyen la orgullosa constatación de la calidad del individuo (y/o su linaje) y de sus inveterados vínculos con la Corona (Apéndice documental, números 19 y 20).

${ }^{13}$ Amén de las referidas en el apéndice, sirvan de ejemplo las 70 onzas de piedra bezoar occidental que en 1598 llevó a Italia el marqués de Este: Ibídem Legajo 53/3, Documentos 2-3; las 12 onzas de piedra bezoar y las muchas bujerías de Indias remitidas, entre otras alhajas, por la princesa de Módena en 1621 -recién arribada a Madrid para profesar en las Descalzas Reales- para regalo de su madre, Isabel de Saboya, y sus hermanos: Legajo 54, Documento 86; el vaso de nigroceronte guarnecido de plata sobredorada que portaba consigo el embajador de la Orden de San Juan de Jerusalén a su retorno a Malta en 1621: Legajo 54, Documentos 90-91; el rosario, las dos cajuelas y dos cofrecillos de caparazón de tortuga, el pedacito de unicornio engastado en plata y las cuatro onzas de piedra bezoar que la abadesa de las Descalzas Reales entregó a finales de 1633 al embajador extraordinario de Vittorio Emanuel de Saboya para regalo de las hijas del duque: Legajo 54, Documentos 197-199; o el huevo de gueso labrado, las tres piedras de puercoespín, el cofrecillo de tortuga con pies y guarniciones de plata y pedrería engastada y las acostumbradas onzas de piedra bezoar que a mediados de 1635 portaba en su valija el también embajador saboyano Ludovico Forni: Legajo 54, Documentos 222 y 223. Cfr. A. PÉREZ DE TUDELA y A. JORDAN, Op. cit., pp. 1-127.

${ }^{14}$ Apéndice documental, números 24, 26, 28, 30, 35, $38-41,45,46,52,55,60$ y 62 . Tres son, por su parte, los 
refieren un mismo bagaje o envío, no siempre proporcionan un mismo testimonio. Así, por ejemplo, ya no serían cinco las cajas de pinturas que el padre Benavides hizo llegar al rey en $1643^{15}$, sino diez: las siete remitidas desde Nápoles por el almirante de Castilla $\mathrm{y}$ las tres encomendadas en Valencia por el duque de Arcos (Apéndice documental, número 52). Por lo demás, nada se dice del accidente sufrido por uno de los carros que transportaba las pinturas desde Zaragoza adonde les dio traslado el jesuita-, que quedarían en un mesón de Cariñena a la espera de que un funcionario de corte volviera al lugar a recogerlas (Apéndice documental, número 53).

Advertimos una sustanciosa merma en el valioso equipaje artístico con el que Alonso Guillén de la Carrera retornó de Nápoles en 1639: si en la memoria castellana se referían 95 pinturas $^{16}$, en la aragonesa, algo posterior, solo se registran 22 , en su mayoría de pequeñas dimensiones. Eso sí, también se hace eco de otros objetos de carácter artístico (Apéndice documental, número 41).

Abundando en esta línea, la información vertida en la memoria de la recámara del marqués Gabriele Riccardi ${ }^{17}$, embajador saliente del gran duque de la Toscana (documento datado en julio de 1640), permite distinguir entre cosas usadas y nuevas, estos es, entre las que el diplomático habría traído desde Florencia al inicio de su misión:

coincidentes con Pérez y Jordan: números 1, 2 y 5; seis los recogidos por García García: números 18, 28, 30, 38, 43 y 60 (cuatro reproducidos por Morán y Rudolf: 28, 30, 38 y 60) y cinco los citados por Torrás: números 18, 28, 30, 38 y 43 (consignados bien por Morán y Rudolf, bien por García García). J. M. MORÁN TURINA y K. RUDOLF, Op. cit., pp. 298-302; J. M. MORÁN TURINA, Op. cit., pp. 547-560; A. PÉREZ DE TUDELA y A. JORDAN, Op. cit., pp. 88-89 y 101; B. J. GARCÍA GARCÍA, "Regalos diplomáticos y bienes suntuarios...", pp. 233-239 y 246249; y S. TORRÁS, Op. cit., pp. 210-218.

${ }^{15}$ J. M. MORÁN TURINA y K. RUDOLF, Op. cit., pp. 302 y J. M. MORÁN TURINA, Op. cit., p. 554.

${ }^{16}$ J. M. MORÁN TURINA, Op. cit., p. 553.

${ }^{17}$ Ibídem.
"Ocho quadros de retratos y dos de Santos. Un Relicario de bronce chiquito" y aquellas que habría adquirido en España: "Un Niño Jesús, un san Juan, dos hechuras de Crucifixo y unos Angeles todo de madera y chi$\cos []$,4 leoncillos de carton dorados y otras niñerias de altares todo de valor de sessenta ducados. Quatro Retraticos de santos y ocho mapas de partes" (Apéndice documental, número 45). Algo desdibujado quedaría, por su parte, el bagaje de su sustituto al frente de la legacía madrileña, Octavio Pucci, que si bien introdujo en España 39 pinturas entre retratos, cuadros de santos y otros motivos ${ }^{18}$, "cassi todos son chicos y son copias" (Apéndice documental, número 46).

En ocasiones, las divergencias, aunque de escaso calado, avanzan información en relación a algún conocido episodio artístico: es el caso del modelo y retrato a cavallo de Felipe $\mathrm{IV}^{19}$, conocidas obras de Martínez Montañés y Velázquez que habrían de servir a la elaboración de la majestuosa escultura ecuestre de Tacca; la información contenida en el pasaporte aragonés da cuenta del itinerario seguido por sendos envoltorios, que de Madrid pasarían a Zaragoza y posteriormente a Barcelona, donde se embarcarían con toda premura, primero, a Génova ${ }^{20} \mathrm{y}$, más tarde, a Florencia (Apéndice documental, número 30).

PASAPORTES Y MEMORIAS DEL ARCHIVO DE LA CORONA DE ARAGÓN

Adentrándonos ya en el examen de los pasaportes y memorias del Archivo de la Corona de Aragón, cabe ordenar el material reunido en tres grupos principales: los documentos que aluden a presentes artísticos recibidos o dispensados por la familia real; los despachos que se refieren a empresas

\footnotetext{
${ }^{18}$ Ibídem.

${ }^{19}$ J. M. MORÁN TURINA y K. RUDOLF, Op. cit, pp. 294 y 299 y J. M. MORÁN TURINA, Op. cit., p. 552.

${ }^{20}$ S. SALORT, Velázquez en Italia, Madrid, 2002, pp. 342-347 (y especialmente, nota 3).
} 
artístico-decorativas cortesanas o vinculadas a los Sitios Reales; y por último, aquellos que ayudan a ponderar la circulación de obras de arte por España. Con todo, estas categorías no son estancas y es común que se vean penetradas por las restantes, informando además sobre cuestiones de interés no menor, caso de la retratística y su papel en las relaciones diplomáticas, la ordenación de las colecciones de algunos personajes principales (incluyendo aquellos objetos que dan idea de los gustos e inclinaciones del período) o el interés que en ciertos casos suscitaba nuestro arte.

\section{Presentes artísticos}

Entre los primeros, es fácil encontrar, sobre todo a comienzos de siglo, un volumen relativamente alto de retratos remitidos desde Madrid a otras cortes europeas unidas por lazos de parentesco ${ }^{21}$, caso de los enviados a Florencia por la reina Margarita a su hermana María Magdalena en 1609 (Apéndice documental, número 7); de los entregados meses más tarde al cardenal de Saboya por mediación de su agente en España, el doctor Niccolò Benigni, entre los que había uno del duque de Lerma (Apéndice documental, número 8); de los cuatro que llevó consigo a Italia, en 1614, el conde de la Mota, embajador del duque de Saboya (Apéndice documental, número 11); o de los "quinze retratos de la Casa Real" encomendados en 1630 a Oliverio Squinquinelli, gentilhombre de cámara del archiduque Leopoldo (Apén-

\footnotetext{
${ }^{21}$ Dentro de un programa de exaltación dinástica afianzado en las artes que hunde sus raíces en los primeros Habsburgo y se impone en todas sus ramificaciones; un programa en el que desempeñarían un papel fundamental -como evidencian muchos de los documentos aquí referidos y se conoce que ocurrió en el siglo XVI- las mujeres Austrias (lo fueran por nacimiento o matrimonio), participando activamente en la propagación de la grandeza y el prestigio de la Casa y favoreciendo los intereses políticos de la misma. Cfr. A. JORDAN, "Mujeres mecenas de la casa de Austria y la infanta Isabel Clara Eugenia", en El arte en la corte de los Archiduques Alberto de Austria e Isabel Clara Eugenia (1598-1633). Un reino imaginado, Madrid, 1999, pp. 118137.
}

dice documental, número 24) ${ }^{22}$. Habitual es también la llegada de los más diversos presentes familiares procedentes de Centroeuropa (en un tráfico que parece declinar con el transcurrir del siglo) ${ }^{23}$ : desde un asombroso reloj con diversas invenziones (probablemente, un pequeño teatro de autómatas remitido, junto con la correspondiente memoria de instrucciones y otros muchos artefactos, por la exquisita archiduquesa Claudia de Medici, heredera y continuadora de la tradición de Ambras (Apéndice documental, número 44), hasta las ricas preseas que el también custodio de la Kunstkammer de Innsbruck, Maximiliano III, hizo llegar a comienzos de la centuria a la emperatriz María, su madre -retirada en las Descalzas Reales-, entre las que se contaban, amén de nuevos relojes, “dos librillos de pergamino escritos de mano con figuras [...] un escriptorio de evano con todo su adereço, una pecezilla sobre rruedas con artilleria, una imagen de Nuestra Señora de piedra yman, [y] otra pieça de la mis-

${ }^{22}$ Asimismo en J. M. MORÁN TURINA y K. RUDOLF, Op. cit., pp. 294 y 298 y J. M. MORÁN TURINA, Op. cit., p. 551. Obras que, como ya apuntaran ambos profesores, cabe vincular a Velázquez y su taller.

${ }^{23}$ Considérese que solo hemos procedido a registrar los documentos que relacionan objetos artísticos destacados o representativos, obviando, las más de las veces, joyas, muebles, colgaduras, ropas, tejidos, vajillas y otras menudencias. La documentación refiere asimismo otros envíos por cuenta de los diferentes miembros de la casa Habsburgo, en ocasiones sin especificación de contenido. Sirvan de ejemplo las diez cajas y cofres (sin más detalle) expedidos desde Flandes a finales de 1634 por el Cardenal-Infante para regalo de la familia real: ACA, Consejo de Aragón, Legajo 55, Documento 95; las diez arcas, tres cofres, dos baúles y una caja (de cuyo contenido nada se dice en la memoria y sí, paradójicamente, en el despacho del rey: joyas, vestidos $\mathrm{y}$ veinte reposteros con armas bordadas) que en abril de 1630 se remitieron a la reina de Hungría: Documentos 71-73; las siete cajas y cofrecicos dirigidos a la propia María de Austria en agosto de 1632: Documentos 8586. O las que en este fecundo intercambio hizo llegar a España la pródiga hermana del rey en julio de 1630: Documentos 74-75; en julio de 1631: Documentos 7778; en julio de 1634: Documento 97; o en noviembre de 1634 (siete cajas -sin más especificación- remitidas desde Viena, vía Génova, por los reyes de Hungría y la emperatriz Eleonora Gonzaga): Documento 99. 
ma piedra" (Apéndice documental, número $1)^{24}$, sin olvidar la formidable cuna de ébano guarnecida con figuras y rosetas de plata sobredorada y enriquecida con toda suerte de detalles artísticos, que, junto con otros muebles y piezas accesorias (incluido un tablero para ajedrez y otros juegos de mesa con $m u$ chas piezas figuradas), envió la emperatriz Eleonora Gonzaga a la reina Isabel con ocasión del parto de la infanta Margarita María Catalina, muerta, no obstante, apenas un mes después de su alumbramiento (Apéndice documental, número 18$)^{25}$.

Y si hasta aquí los regalos intercambiados revisten un carácter eminentemente familiar, convendría ahora referir algunos de los remitidos por aristócratas y allegados a la corte; unas dádivas con las que no buscarían sino favorecer sus propios intereses o seguir disfrutando del favor real (aun cuando fueran expresión de su liberalidad y acaso de su fidelidad o proximidad al monarca). Entre estos, cabría destacar un libro de horas que fue de María Estuardo (quizá aquel que, junto con su crucifijo -también arribado a España por rara coincidencia-, llevaba entre sus ropas la reina de Escocia cuando fue decapitada) ${ }^{26}$ con el que el es-

${ }^{24}$ Asimismo en A. PÉREZ DE TUDELA y A. JORDAN, Op. cit., p. 88.

${ }^{25}$ Asimismo en B. J. GARCÍA GARCÍA, "Regalos diplomáticos y bienes suntuarios...", pp. 246-249.

${ }^{26}$ Una cruz de oro y esmaltes que fue de Isabel de Borbón y más tarde de la condesa de Escalante. A su muerte, en 1681, pasó por legado testamentario a las Comendadoras de Santiago de Valladolid. Transferida, ya en el siglo XIX, al Consejo de Órdenes Militares, fue entregada a la reina María Cristina de Austria con motivo de sus bodas con Alfonso XII: F. R. UHAGÓN, "El Santo Cristo de María Stuart", Revista de Archivos, Bibliotecas y Museos, Año V, 1901, pp. 1-10 y 102-125. La cruz desapareció del relicario de la capilla del Palacio Real durante la Guerra Civil: MARQUÉS DE LOZOYA, "Algunas pérdidas del Patrimonio Nacional y de los patronatos reales en los años de 1936-1939", Archivo Español de Arte, 138, 1962, p. 94. No fue esta cruz la única pieza perteneciente a la reina mártir que arribó a España: en 1593, Antonio Voto, guardajoyas de Felipe II, entregaba al prior del Escorial "una sortija de oro tallada y esmaltada de negro, engastado en ella un diamante [...] que fue de la Reyna de Escocia que la de pía y aventurero inglés sir Anthony Shirley quiso obsequiar a la reina en 1611 (Apéndice documental, números 9a y 9b); el delicado instrumento de tecla, invención nueva, que hizo fabricar en Roma el doctor Bartolomé Generardo en 1636 (Apéndice documental, número 27); las libreas que a la sazón hizo tejer el obispo de Teruel para los criados de la Casa del Rey (Apéndice documental, número 51); o las suntuosas finezas con que la nobleza de los territorios periféricos procuró agasajar a los soberanos, sea el caso de las imágenes de cristal, los dos escritorios y los dos bufetes conformes remitidos en 1645 por el marqués de Matonte (Apéndice documental, número 55) o el de los riquísimos presentes que en 1636 hizo llegar el entonces presidente y capitán general del reino de Sicilia Luis Guillén de Moncada (no referidos, sin embargo, con toda puntualidad en los registros), a saber: cuatro escritorios de ébano lujosamente labrados y guarnecidos, los escaparates de cristal de roca que los contenían, una hermosa carroza tirada por siete mulas blancas para el príncipe, una silla de manos para la reina, el conjunto de los criados que los acompañaban y "un raro protento [sic] de naturaleza, que era un moço de 16 años hermafrodita, ricamente vestido, el qual havía sido muger [...] y se bolvió hombre" ${ }^{\prime 27}$, de

Inglaterra hizo degollar": F. R. UHAGÓN, Op. cit., p. 114. Desconocemos el paradero de esta pieza. Fueran o no estas Horas las que la reina Stuart llevó consigo al patíbulo, es de advertir el interés de nuestros monarcas por adquirir reliquias de la mártir escocesa -sin duda animados por su valor religioso, pero también político y representativo-, lo que haría de este presente una pieza especialmente celebrada.

${ }^{27}$ Como así se refiere en la correspondencia de los padres Jesuitas: REAL ACADEMIA DE LA HISTORIA, Memorial Histórico Español, Tomo XIV, Madrid, 1862, pp. 76-79 (carta de 29 de marzo de 1637) y en las noticias de G. GASCÓN DE TORQUEMADA, Gaçeta y nuevas de la Corte de España desde el año 1600 en adelante, Madrid, 1991, pp. 405-406 (del que ha sido extraída la cita). La documentación de archivo se hace eco de la confusión que causó en Madrid este envío, del que no se tenía exacta noticia previa -lo que explicaría las pequeñas divergencias existentes entre los presentes referidos por los cronistas y los participados en un primer momento a los consejeros-, siendo preciso convocar a un agente 
tal estimación que fueron exhibidos en pública cabalgata por las principales calles de Madrid (Apéndice documental, número 33). Sospechamos que no sería este el único regalo extraordinario con el que habría de prodigarse el dadivoso y atrabiliario duque ${ }^{28}$, que en otoño de 1642, siguiendo al rey en la jornada de Aragón, introducía en España -como parte de su recámara- tres estatuas de bronce y una de mármol, ocho bustos de emperadores asimismo de bronce y al menos quince pinturas (Apéndice documental, número 48).

Del que sí podemos dar fe es de un nuevo y desconocido lote de pinturas enviado a mediados de 1657 (y no entregado sino a comienzos del 58) por otro de los munificentes aristócratas italianos al servicio de la Corona española, el príncipe Ludovisi (Apéndice documental, número 57); un lote que viajó en compañía de los célebres tableros de pórfido despachados por el duque de Terranova para decoración del Salón de los Espejos del Alcázar y los doce bustos de emperadores, también de pórfido, probablemente destinados a la Galería del Mediodía del palacio madrileño (Apéndice documental, número 56). Embarcados -unos y otras- en Civitavecchia

del de Montalto para dar cuenta de lo "que trahe para servicio de Vuestra Majestad, porque esto tiene diferente inspección": ACA, Consejo de Aragón, Legajo 54, Documento 250.

\footnotetext{
${ }^{28}$ Aunqueno recogidoenlos pasaportes conservados, estos presentes completarían un envío anterior del que también tenemos constancia por la correspondencia de los padres jesuitas y que se compondría de: "un velon de plata con seis candeleros grandes que nacen del tronco, de hechura extraordinaria, y con una muy grande bola de plata y cristal de valor de 1.300 ducados; una fuente y aguamanil de plata embutida de corales, hermosísima y con algunas piezas de oro esmaltadas, que costó en Italia 2.000 ducados, y una imagen de la Asunción de Nuestra Señora, de coral, grande, con todos los misterios del Rosario hechos de coral, y una orden de coral muy galana, toda guarnecida de oro y plata, de valor de 1.200 ducados en Italia [...] y dijo esperaba otras cosas no inferiores que por no haber llegado no iba presente tan cumplido como deseaba el duque": REAL ACADEMIA DE LA HISTORIA, Memorial Histórico Español, Tomo XIII, Madrid, 1861, p. 397 (carta de 22 de abril de 1636).
}

y arribados a Barcelona a finales de agosto de 1657, debieron ser sometidos a cuarentena y un posterior lavado para ahuyentar la peste que a la sazón padecían algunas regiones italianas ${ }^{29}$.

Y es con este envío, vinculado a las iniciativas que desde mediados de siglo perseguían la modernización de la crujía meridional del Alcázar madrileño, que abrimos el segundo de los bloques documentales, aquel que atiende a las empresas artísticas cortesanas y a las obras de adecuación o provisión de los Sitios Reales.

\section{SITIOS Y EMPRESAS REALES}

Amén de las pinturas transferidas por cuenta de Castel Rodrigo, Arcos y el almirante de Castilla, a las que ya nos hemos referido con anterioridad, un envío destaca sobre todos los demás: el de la cama endoselada que en 1640 remitía desde Milán el marqués de Leganés para servicio de la familia real; un suntuoso lecho de primorosa labor que se hacía acompañar de cinco frontales de altar, cuatro para los laterales y uno grande para el mayor, diversos ornamentos litúrgicos y otros muebles accesorios (Apéndice documental, número 43) ${ }^{30}$. Desconocemos el destino de estas piezas variopintas, si bien todo parece indicar que se encaminarían a Buen Retiro $^{31}$, habida cuenta de la fecha en que

\footnotetext{
${ }^{29}$ Remitimos a un artículo de inminente publicación en el que reexaminamos las relaciones artísticas entre el príncipe Ludovisi y la Corona española y damos cuenta de este cuasinovelesco episodio: R. LÓPEZ CONDE, "Las relaciones artísticas entre el príncipe Ludovisi y la monarquía española. Nuevos datos y evidencias" [en vías de publicación]. Cfr. asimismo D. GARCÍA CUETO, “Don Diego de Aragón, IV Duque de Terranova, y el envío de esculturas para Felipe IV durante su embajada en Roma (1654-1657)", Archivo Español de Arte, 311, 2005, pp. 317-322.
}

${ }^{30}$ Asimismo en B. J. GARCÍA GARCÍA, "Regalos diplomáticos y bienes suntuarios...", pp. 233-234. El profesor García vinculó esta lujosa remesa a Buen Retiro (capilla y dormitorio de aparato del rey).

${ }^{31}$ La referencia a una "sillita para el príncipe" nos hace pensar que su destino fuera el Cuarto del heredero, situado en la Galería de Toledo, tras el claustro de San 
tuvo lugar el envío y la vinculación de Le-

Jerónimo. Que Buen Retiro requería camas (pese al fastuoso lecho labrado por el platero Jorge de Quevedo en 1634) y que el rey mostraba propensión -o comenzó a mostrarla- por las de hechura italiana, nos lo sugiere el hecho de que en 1637 se hiciera regalar aquella que poseía el banquero genovés Carlo Strata en su fastuosa morada de la carrera de San Jerónimo; una cama poéticamente descrita por la dramaturga Ana Caro de Mallén y que parece mostrar ciertas concomitancias con la enviada por Leganés: “De vna cama de rojo terciopelo, / Que en tela à flores, rica se aforraua, / Si maravillas huuo, yo rezelo, / Que aquesta fue la Marauilla Octaua, / Quando por su valor mejor pudiera / Ser de todas las siete, la primera. // La madera, que solio peregrino / A suspender bastò, embaraço al viento, / Euano negro, ò azauache fino / Se vio milagro, se zelò portento...": A. CARO DE MALLÉN, Contexto de las reales fiestas que se hizieron en el Palacio del Bven Retiro, Madrid, 1637, fol. 8r. Asimismo, el incendio que coetáneamente sufrió Buen Retiro -y que hizo necesarios reparos en camas, escritorios, bufetes y demás alhajas de ébano, marfil y bronce- haría de este lecho una pieza mueble no solo apetecida, sino también necesaria. Para las referencias a Buen Retiro: J. BROWN y J. H. ELLIOT, Un palacio para el rey, Madrid, 2003, pp. 108 y 211 y J. M. AZCÁRATE, "Anales de la construcción del Buen Retiro", Anales del Instituto de Estudios Madrileños, 1, 1996, pp. 123-124. El de Leganés no sería además el único lecho venido de Italia para el nuevo palacio del rey. Así lo revela Olivares en una carta-memorial enviada a Chumacero en octubre de 1641, en la que el conde-duque, hostigado por las críticas a su gestión y el excesivo gasto incurrido en la construcción del Retiro, refería al entonces embajador extraordinario en Roma que "es menester decir en una palabra la verdad. Buen Retiro del Patrimonio Real, de sissas, alcavalas, rentas, derechos, donativos ni otra ninguna contribuzion ni gracia no ha costado a S.M. 500 ducados salbo lo que el conde Monterrey embio en unas tres o cuatro colgaduras, y en una cama lo cual se le pago de la hazienda de S.M. y de su Patrimonio. Hiço mal una y ynfinitas vezes y por muchos títulos, sea el primero, que S.M. no quería que de su haçienda Real se gastase nada, lo segundo porque lo que ymbio no a serbido de nada ni lo estimo S.M. ni se le dieron gracias por ello ni aun apenas se le aviso del recivo; lo tercero y más apretado, por que sabiendo S.M. que lo queria embiar por cartas repetidas una, dos y más vezes le mandó que por ningun caso lo hiciese por que S.M. no lo quería ni era menester. Si por hacer gusto al Principe Ludovisio lo hizo sera quarta raçon de mal hecho": Biblioteca Nacional de España, Ms. 10984, fol. 239v-245v (Carta del conde-duque de Olivares a don Juan Chumacero, 22 de octubre de 1641); transcrita con ligeras modificaciones en: J. H. ELLIOT y J. F. DE LA PEÑA, Memoriales y cartas del conde duque de Olivares, Vol. II, Madrid, 1981, pp. 213-216 (doc. XVII). Tal vez, ganés con dicha empresa artística ${ }^{32}$. También se hicieron llegar quince cajas con vidrieras venecianas (Apéndice documental, número 29) y dieciséis mesas de jaspe labradas por la ciudad de Tortosa (Apéndice documental, número 28$)^{33}$, despachadas unas y otras en 1634 para servicio y adorno del flamante palacio madrileño.

Y no fueron las únicas vidrieras remitidas desde Italia ni los únicos mármoles extraídos de Tortosa para los sitios y palacios de Su Majestad: documentadas quedan las consabidas partidas de jaspe remitidas desde la ciudad tarraconense para el arranque de las obras del Panteón escurialense (Apéndice documental, números 13 y 14), como también las vidrieras de colores enviadas en 1673 por el marqués de Astorga, virrey de

la cama franqueada por Leganés viniera a reemplazar el menospreciado lecho remitido por don Manuel de Fonseca y Zúñiga.

${ }^{32}$ Quizá sea la referida cama la misma que se oculta tras una larga entrada de la testamentaría de Carlos II: "Ytten una cama de platta que tiene quattro pedresttales quadrados con sus molduras por lo altto y vajo con vn bozel que va jugando juntto al plintto que cada vno tiene un tornillo grande con quattro pilares entteros entorchados torzidos que attornillan en los dichos pedresttales con un remate en lo altto para las gotteras y cada pilar con su asa y capittel y una cabezera con ocho balaustres enttorchados con vn plintto de plata quadrado en que attornillan y en lo altto una corniza con un bozel a dos azes y ocho manzanillas con doze gallones cada vna en lo vajo y otros doze en lo altto y los casquillos y alcazattas en que se ponen las barillas son de yerro platteados...": G. FERNÁNDEZ BAYTON, Inventarios Reales. Testamentaría del rey Carlos II. 17011703, Vol. I, Madrid, 1975, p. 191 (Alcázar de Madrid, Oficio de Guardajoyas, número 27). No debe extrañar que por entonces se hallara en el Alcázar, habida cuenta de la nada infrecuente traslación de piezas entre los distintos Sitios Reales (del que da fe un repaso, incluso somero, de aquel prolijo inventario). Una cama que, por lo demás, ha sido puesta en relación con la representada en el conocido cuadro de Sebastián Muñoz Las exequias de María Luisa de Orleans: P. BENITO GARCÍA, "El Alcázar vestido de seda", en F. CHECA CREMADES (ed.), El Real Alcázar de Madrid, Madrid, 1994, p. 314.

${ }^{33}$ Cfr. Y. GIL SAURA, "Jaspes de Tortosa para el Palacio del Buen Retiro de Madrid", Anuario del Departamento de Historia y Teoría del Arte, 19, 2007, pp. 67-78. 
Nápoles, para el palacio de Aranjuez (Apéndice documental, número 61$)^{34}$. Otros envíos consignados para los Reales Sitios serían: los ocho candeleros de cristal labrados a comienzos de siglo en Milán para el oratorio de la reina (Apéndice documental, número $3)^{35}$; las cuatro alfombras venecianas que se

${ }^{34}$ Envío vinculado a las obras que a la sazón tenían lugar en la vieja capilla de palacio: "una tribuna alta, volada á la parte esterior, cubierta de cristales, que, dando vuelta á tres de sus cuatro paredes, desfiguraba la capilla": C. LÓPEZ Y MALTA, Historia descriptiva del Real Sitio de Aranjuez, Madrid, 1868, p. 181. Según conocemos por un despacho firmado en Aranjuez por la reina Mariana, pocos meses después, en marzo de 1674, el de Astorga hacía llegar desde Nápoles tres nuevas cajas con "algunas cosas para mi servicio"; un envío que quizá deba ponerse en relación con la sobredicha obra: ACA, Consejo de Aragón, Legajo 55, Documento 259.

${ }^{35}$ Un espacio en el que concentraba sus atenciones artísticas la reina, como explícitamente se advierte en la Relazione segreta delle cose della corte di Spagna (1605), agudísimo informe confidencial elaborado por Orazio della Rena, secretario de la embajada florentina en Madrid entre 1593 y 1605, con muy acertadas consideraciones sobre la práctica del agasajo y el regalo diplomático en la corte española. Della Rena recomendaba a Ferdinando I "inviare alla Regina quadri, et pitture di divozione di diverse sorti, ma di mano di pittor celebre, et saranno carissime perche si diletta molto d'adornare in suo oratorio, dove ne ha raccolte assai, et preme per hora in questo con grand'estremo, vasi grandi di cristallo [...] et coppe di curiose fatture, et peregrine sarebbon anco ben recevute. Et se partorisse un figliolo non saria fuor di squadra una culla riccha et scelta...": E. GOLDBERG, "State gifts from the Medici to the court of Philip III: The Relazione segreta of Orazio della Rena", en J. L. COLOMER (ed.), Op. cit., p. 121. Y a fe cierta que así lo hizo: en 1607 , el gran duque remitía para el oratorio de la reina ocho quadretti con escenas de la vida de la Virgen obrados por Alessandro y Cristofano Allori, Jacopo da Empoli, Ligozzi, Poccetti, Cigoli, Passignano y Marucelli. Muchos fueron también los bicchieri, vasi et bizerrie di cristallo que salieron de las talleres pisanos con destino a la corte; piezas de gran estimación, demandadas por cientos, y que apenas era posible encontrar en Madrid, como así lo reportan los funcionarios de la legacía toscana: "Chiego vetri, e gli chieggo presto perchè [...] son domandati da molti, et in vero che qua non si può mandar cosa più grata"; "La Maestà della Regina va cercando vetri di Venezia, che in tutto Madrid non se ne trova": E. GOLDBERG, "Artistic relations between the Medici and the Spanish courts, 1587-1621: Part I \& II", The Burlington Magazine, 1115 y 1121, 1996, pp. 109-110 y 537. Por lo demás, nótese la idoneidad de muchos de los envíos y presentes, procedieren o no de hicieron traer en 1613 para servicio de los reyes (Apéndice documental, número 10); o aquella que ofreció a las Descalzas Reales don Pedro de Gregorio, presidente del Tribunal de la Gran Corte de Sicilia, en 1659 (Apéndice documental, número 59). Cierran este segundo grupo, los pasaportes concedidos a los aposentadores que hicieron con el rey las jornadas de Aragón: Alonso Carbonel para la traslación a Tarazona en 1643 y Pedro de Torres para el retorno a Madrid a finales del mismo año. Este último repetiría desplazamiento en 1645 (Apéndice documental, números 49,51 y 54).

\section{Circulación de obras de arte por España}

En lo que concierne a la circulación de obras de arte por nuestro país, tercer y último bloque de esta serie, varias son las recámaras de funcionarios y diplomáticos al servicio de la monarquía hispánica que creemos preciso destacar. Ciertamente, no es mucha la información que trasciende de las memorias conservadas ${ }^{36}$, ni muchas parecen ser las piezas artísticas de cierta envergadura trasegadas; la propia caducidad de las misiones diplomáticas, las contingencias del traslado y una marcada preferencia por la orfebrería, de fácil transporte, acúmulo y ostentación, limitarían el alcance de la documentación. Con todo, es en este grupo que encontramos la única referencia explícita a un artista: el tintoretto que, junto con una segunda pintura veneciana, fue del conde Carlo Rasini y de Madrid pasó a Milán en 1693 (Apéndice documental, número 66$)^{37}$.

Florencia, aquí consignados.

${ }^{36} \mathrm{O}$ no en lo que toca a nuestros propósitos. Mucho se podría decir, en todo caso, en relación a la vida material de algunos aristócratas, a la suntuosa composición y espectacular traslación de sus recámaras y séquitos de conformidad con unas necesidades cotidianas y representativas.

${ }^{37}$ Y que quizá pueda identificarse con una Piedad del Robusti propiedad de la familia Rasini. En cuanto a la segunda de las pinturas, se sabe que en la quadrería familiar había obras de Palma el Viejo, Tiziano o el Veronese. El propio Carlo poseía-según hace constar en un testamento dictado en 1697, en vísperas de un nuevo 
Por otra parte, varias son las pinturas, esculturas y tapices viexos y usados (de contenido, siempre que referido, religioso) con las que otro noble italiano al servicio de la Corona, el napolitano Francisco de Moles, duque de Parete, partió de la capital hacia su embajada en Alemania en 1700 (Apéndice documental, número 69). También de finales de siglo es la recámara que el marqués de Villena, a la sazón general de la caballería, llevó consigo a Barcelona para adorno de su casa; entre las piezas reseñadas: cuarenta tapices repartidos en cinco series de figuras grandes, galerías y boscajerías, dos pinturas de Cristo y numerosas láminas (Apéndice documental, número 64). Treinta y cinco fueron, por su parte, los tapices trasladados por Francisco de Melo a Saboya en 1632, entre los que viajaban las series Historia de los Dioses e Historia de Eneas que el profesor Bernardo J. García vinculó -no sin razón y con toda reserva- a una fastuosa remesa destinada al monarca y que a la luz de este documento podemos restituir a su efectivo propietario (Apéndice documental, número 25) ${ }^{38}$.

Y hasta aquí, el repaso de la valiosa documentación hallada entre los pasaportes de las generalidades aragonesas. Muchas son las noticias que dejamos sin comentar, si bien las glosadas pueden dar cuenta de la riqueza de esta serie prácticamente inédita.

\section{APÉNDICE DOCUMENTAL}

1) 1600, Abril, 5. ACA, Consejo de Aragón, Legajo 55, Documento $22^{39}$.

viaje a España- un retrato del rey Felipe IV y otro de la reina Isabel de Borbón di mano di Diego Velasquez: G. A. VERGANI, "La decorazione delle sale del piano terra", en G. A. VERGANI (ed.), Il palazzo dei conti Rasini a Cavenago di Brianza, Cavenago di Brianza, 1997, p. 110.

38 Presentes asimismo en el bagaje acarreado por Melo a su vuelta de Flandes en 1644. Junto con su propia recámara, Melo dio entonces traslado del imponente legado resultante de la reunión de las casas mortuorias de Isabel Clara Eugenia y el cardenal-infante don Fernando: B. J. GARCÍA GARCÍA, "El legado de arte...", p. 147 y notas 68 y 69.

39 Todos los textos del Apéndice documental
Desde Alemania, el archiduque Maximiliano envía a la emperatriz María de Austria, su madre: "un relox quadrado, dos librillos de pergamino escritos de mano con figuras, otro librico de cobre dorado, otros quatro reloxicos pequeños, diez sortijas de oro, un escriptorio de evano con todo su adereço, una pecezilla sobre rruedas con artilleria, seis librillos de memoria, una imagen de Nuestra Señora de piedra yman, otra pieça de la misma piedra".

\section{2) 1600, Mayo, $6^{40}$. Documento 34.}

La emperatriz envía a Alemania por el camino de Aragón y Cataluña: "unas imagines de Nuestra Señora para sor Madalena Grienberguerin [...] una arquita de cuerno guarneçida de plata [...] un cuerno de bada envuelto en frisa blanca [...] un par de galgos castaños [...] una copa de cuerno de Bada [...] un barquillo de plata dorada que pesa noventa Reales".

3) 1605, Enero, 3. Documento 32.

La reina manda "que se haga un passaporte para [...] una caxa con ocho candeleros de cristal que se an hecho hazer en Milan para servicio de su oratorio [...] la cual trujo hasta Zaragoza el embajador que vino de Alemania".

4) 1605, Enero, 5. Legajo 54, Documento 40.

El señor de Castel Argento, que viene por negocios de Carlo Emanuele de Saboya, trae para regalo de los hijos del duque, residentes en esta corte: "quadros de pintura".

pertenecen al mismo fondo documental (Consejo de Aragón) del Archivo de la Corona de Aragón, cambiando únicamente el número de legajo al que pertenecen, por lo que, para no extender excesivamente el artículo, se citará únicamente la numeración de ambos, o solamente la del documento cuando pertenezca al mismo legajo que el texto anterior. Por la misma razón, y dada la brevedad de los extractos documentales, se obvia el regesto del documento y la composición formal habitual de su presentación (Nota de la Editora).

${ }^{40}$ Sin datar; la fecha ha sido extraída de A. PÉREZ DE TUDELA y A. JORDAN, Op. cit., p. 89. 
5) 1609, Marzo, 14. Legajo 55, Documento 46 .

La infanta doña Margarita envía al rey de Hungría, su hermano: "un rosario de cocos, una caxita de nacar de las Indias y, dentro della, seis piedras vezales de las Indias oçidentales [...] una copia de cuerno de bada, una piedra vezar [...] un enboltorio pequeño con una Imagen de santa Clara".

6) 1609, Marzo, 30. Documento 47.

"Su Majestad manda [...] dexen pasar libremente [...] un escritorio cubierto de terçiopelo negro guarnezido de figuras de plata por dentro que de Alemania se trae para Su Majestad".

7) 1609, Noviembre, 26. Documentos 4850.

La reina envía a Florencia para regalo de su hermana María Magdalena de Austria: "una caja de oro quaxada de diamantes por una parte y otra dentro el Retrato del Rey nuestro señor y de la Reyna nuestra señora que tiene noventa y dos diamantes quadrado y triangulado. Un Rosario de cocos guarneçido de oro con una coluna de diamantes pendiente y una Reliquia dentro [...] Mas otro Rosario de cocos guarneçido de oro y unas muertes por extremos con otra coluna de diamantes pendiente [...] Una caxa de plata quadrada y nielada y dorada y dentro della una piedra beçal grande [...] Mas otras dos piedras beçales pequeñas [...] Mas dos Retratos de Su Majestad y de la Reyna nuestra señora en lienzo".

8) 1610, Junio, 12. Legajo 54, Documentos 58-59.

El doctor Niccolò Benigni, agente del cardenal de Saboya, lleva consigo a Italia: "Los retratos de Sus Majestades, que Dios guarde, y del señor Duque de Lerma".

9a) 1611, Enero, 24-Febrero, 11. Legajo 55, Documentos 52-53.

El conde don Antonio Escherlei (sir Anthony Shirley) envía por mediación del padre Crisuelo de la Compañía de Jesús "unas oras de nuestra señora illuminadas, que fueron de la Reyna de Escocia, para [...] la Reyna nuestra señora".

09b) Sin datar. Documento 122.

"Rafael Moro Ingles criado del Conde don Antonio Seherley, general de los navios de alto borde en el mar Mediteraneo, dijo que embiandome el dicho conde desde Barcelona a esta Corte con un despacho juntamente me entrego un librillo [...] de las horas de Nuestra Señora con algunas yluminaçiones y con las armas de la Reyna de Scoçia para que en llegando a esta corte le diese al padre Jusepe de Cresuelo de la Compañía de Jesús con horden para que le presentase a la majestad de la Reyna".

10) 1613, Junio, 26. Documento 56.

El rey ordena que se devuelvan a Fernando de Paredes, tesorero de la Santa Cruzada, los derechos del general por cuatro alfombras que vinieron de Venecia para el servicio real.

11) 1614, Octubre, 11. Legajo 53/3, Documentos 11-12.

El conde de la Mota, embajador de Saboya, lleva consigo a Italia: "Tres retratos chicos del rey, príncipe y ynfanta y otro grande del rey [...] Veynte camafeos con oro en un sombrero".

12) 1618, Octubre, 11. Documentos 1416.

El embajador francés Bauffremont lleva consigo a Francia: "un relicario pequeño con un cerco de plata. Otro relicario pequeño ciñido de oro [...] Una medalla dorada de la effigie del Rey Cristianísimo [...] Dos relicarios bordados de oro y plata uno verde y el otro colorado. Dos reloxes con caxas de plata".

13) 1618, Diciembre, 3. Legajo 55, Documento 61 .

"Para la obra del Pantheon que por mandado de Vuestra Majestad se haze en el Monasterio de San Lorenço el Real es menester cantidad de piedras de jaspe que se han de sacar de Cataluña y Aragon francas 
de derechos, y que assi se le diessen los despachos necessarios para ello".

14) 1619, Octubre, 7. Documento 62.

"En Tortossa an asistido algunas personas por mandado de Su Majestad a sacar cierta piedra para la obra que en adorno del pantheon donde estan los cuerpos reales, se haze en el Monasterio de Santo Lorenço, y porque [...] en Alicante les obligaron a hazer deposito de lo que montavan los derechos [...] para cossa de veinte y quatro carros que vienen agora".

15) 1620, Noviembre, 7. Legajo 53/3, Documentos 18-19.

Gabriel Morasent, embajador francés, lleva consigo a Francia: "Un relicario pequeño siñido de oro. Otro relicario pequeño con un cerco de plata [...] Una medalla de plata dorada del Rey Cristianísimo [...] Dos relicarios bordados de oro y plata, uno verde y el otro colorado, encaxados en ebano. Dos relojes con caxas de plata".

16) 1622, Octubre, 27. Documentos 3638.

Monseñor Adam Makowski, embajador plenipotenciario del rey de Polonia, trae consigo desde Nápoles: "Una caxeta con diversos quadros de pinturas [...] algunas labores de cristales de montaria, como cruces, reliquiaros y cabeças de muertes".

17) 1622, Diciembre, 16. Documentos 39-40 y $52-53$.

Battista Serra, embajador de Génova, trae consigo a Madrid: "Tapisserias diversos [sic] para colgar ocho aposentos", que no declaró a su salida casi cinco años después.

18) 1624, Enero, 30. Legajo 55, Documentos 63-64.

Presente que la emperatriz envía a la reina Isabel con ocasión del parto de la infanta Margarita María Catalina: "una cuna de hevano guarnezida con figuras y rosetas de plata sobredoradas que esta en el ayre con dos pies grandes de la misma labor. Otra cama de hebano y plata diferente que esta firme en el suelo. Un baño de hevano guarnezido de plata, es para bañar la criatura como se husa en Alemania. Quatro colunas de hevano guarnezidas de plata como las cunas para sustentar el cielo de la cuna que es de brocado con sus hierros sobredorados. Un quadro grande hecho de figuras de plata relevadas guarnezido de plata. Una cama de brocado de plata y oro con sus franxas de lo mismo debajo de la qual se pone la cuna. Dos taburetes de hebano y brocado de oro con un tablero para jugar el axedres y otros juegos hecho de hebano con muchas figuras. Un almario de hebano repartido en tres partes o pieças guarnezido y labrado con figuras y rosetas de plata dentro de las quales ay lo siguiente: Un crucifixo con la Virgen Nuestra Señora y san Juan de plata con la cruz y pie de hebano. Tres piramides de hebano guarnezidas de plata. Un espejo grande guarnezido de plata [... sigue la relación de un sinnúmero de piezas de plata para servicio del recién nacido y la parturienta]. Quatro flores grandes de plata esmaltados para encima de los pilares de la cama [...]. Un clavicordio de hevano y marfil. Mas un arco de plata sobredorada de lindissima echura para encima de la cuna para sustentar el paño quando la cubren y se entiende que todo es sobredorado".

19) 1625, Abril, 25. Legajo 54, Documentos 114-115.

Juan de Brent, criado del duque de Neoburgo, que va a servir al rey en Italia: "tres bueltas de cadena de oro con una medalla del Retrato del Rey don Felipe segundo [...] la cual trajo de Alemania".

20) 1625, Julio, 3. Documentos 118-119.

Un gentilhombre de la Cámara del emperador [¿Grafino Marcan o Marchan?], vuelve a Alemania y lleva consigo: "Una medalla de oro con el retrato del Rey Phelipe tercero".

21) 1627, Junio, 19. Legajo 53/3, Documentos 48-49.

Luigi Mocenigo, que viene a España por embajador de la Serenísima, trae en su 
recámara: “Dos pinturas en cobre y una en piedra".

22) 1627 , Junio, 25. Documentos 50-51.

Un secretario del rey de Polonia que pasa a Italia: "una cadena de oro de balor de ochocientos ducados que tiene pendiente una medalla de la figura de Su Majestad".

23) 1629, Junio, 23. Legajo 54, Documentos 147-148.

El abad Scaglia, embajador extraordinario del duque de Saboya, lleva consigo a Italia: "De bezahar oriental diez onzas. De occidental cinquenta onzas [...]. Una caxita con muchos diamantes y un retrato en el medio".

24) 1630, Marzo, 12. Documentos 164165.

Oliverio Squinquinelli, gentilhombre del archiduque Leopoldo, lleva consigo a Alemania: "Ventiquatro onzas de piedra vezar occidental. Quinze retratos de la Casa Real. Otros cinco retratos diferentes. Dieziseis pinturas de Mapas diferentes [...]. Una dozena de diferentes piezas de alabastro".

25) 1632, Febrero, 18. Legajo 53/3, Documentos 68-69.

Francisco de Melo lleva consigo a Saboya: "Dos Camas de palosanto del Brasil con bronçes dorados [...] Un coche de terciopelo y una litera de damasco [...] Dos escritorios con imagenes, reliquias y cosas de devoción [...] Veynte y dos tapices con sus sobrepuertas y sobreventanas usados y viejos ya. Treçe tapices a medio uso de las Istorias de los dioses y Eneas".

26) 1632, Mayo, 18. Legajo 54, Documentos 178-180.

El marqués de Castañeda, que va a servir como embajador en Alemania, lleva consigo: "quatro tapiçerias que hazen ocho caxas [...] Una caxa de pinturas".

27) 1633, Octubre, 31. Legajo 55, Documento 93.
El doctor Bartolomé Generrardo remite al rey "un instrumento de tecla invençion nueva que avia hecho hazer en Roma para mi servicio"

28) 1634, Junio, 1. Documento 96.

"La ciudad de Tortossa a hecho labrar diez y seis messas de jaspe que se le pidieron para el servicio y adorno de la cassa de Buen Retiro".

29) 1634, Diciembre, 20. Documento 100.

Pasaporte para "quinçe caxas de vidrieras que vienen de Veneçia" para servicio del rey.

30) 1636, Enero, 20. Documento 114.

"Que se envie a Florencia un modelo y retrato a cavallo mio, para que alla se haga de bronçe, daranse las ordenes neçesarias para que en todos los Puertos de [...] la corona de Aragón los aduaneros y guardas no abran de ninguna manera los emboltorios en que va el dicho modelo y retrato y lo dexen pasar libremente, y escrivirase tambien al Virrey de Çaragoza para que no los suelten ni detengan alli y al Virrey de Cataluña se le avise que con la primera Galera que partiese para Ytalia haga llevar en ella los dichos emboltorios encargando mucho que vayan bien y que se entreguen en Genova a quien yran endereçados".

31) 1636, Mayo, 24. Documentos 116117.

"El obispo de Teruel ha hecho texer para la librea que he mandado se de a los criados de mi casa tres mil baras de paño [...] amarillo".

32) 1636, Junio, 13-Agosto, 28. Legajo 53/3, Documentos 72-76.

Fulvio Testi, embajador extraordinario del duque de Modena, que vuelve a Italia: "otro relox mayor de echura de torrezilla [...] Un papagayo".

33) 1636, Junio, 26-Octubre, 20. Legajo 54, Documentos 250-253. 
Presente que el duque de Montalto remite desde Sicilia para la familia real: "Tres escritorios de coral con sus caxas de vidros guarnecidas de plata. Una silla de manos de tela coral y plata con dos esclavos vestidos de lo mesmo. Una carroçilla de tela con sus machos blancos".

34) 1637, Mayo, 3. Legajo 53/3, Documentos 79-80.

Agostino de Mari, embajador entrante de Génova, trae consigo a España: "Tapices para quatro aposentos".

35) 1637, Mayo, 3. Documentos 81-82.

Jacome di Franqui, embajador saliente de Génova, lleva consigo a Italia: “diez paños de tapices [...] Quatro quadros de pintura".

36) 1637, Octubre, 2. Legajo 54, Documentos 263-265.

El conde de Solre, embajador extraordinario de Felipe IV en Alemania y Polonia, trae consigo a España: "tres caxas con tres cavezas de bronze [...] y un niño Jesus de plata, reliquias y agnus dei [...] una piel de la gran bestia con sus ramos y uñas, unas colunas de piedra".

37) 1638, Junio, 17. Documentos 273-274.

Michel Maÿr, ministro de cámara del elector de Baviera, lleva consigo a Alemania: "Una cadena de seiscientos escudos con la efigie del rey nuestro señor de que Su Majestad le ha hecho merced".

38) 1639, Febrero, 24. Legajo 55, Documento 124 .

El marqués de Castel Rodrigo envía desde Roma "siete cajas de cerca de diez y seis palmos de largo que estan con sus cubiertas de Ancho selladas con las armas del Marques [...] en que vienen algunas pinturas que embia para mi servicio y adorno de Buen retiro, [que] vengan libres de derechos, $y$ sin que en los puertos se consientan abrir para que no sean maltratadas las pinturas y molduras que vienen en las cajas".
39) 1639, Mayo, 9. Legajo 53/3, Documentos 96-97.

Annibale Gonzaga, embajador extraordinario del emperador, lleva consigo a Alemania: "Retratos de Sus Majestades y Alteza".

40) 1639, Mayo, 21-Julio, 2. Documentos 98-100.

Fulvio Testi, embajador extraordinario del duque de Módena, lleva consigo a Italia: "quatro onças de piedra Vezar. Once Retratos entre grandes y pequeños ${ }^{41}[\ldots]$ Dos papagayos".

41) 1639, Julio, 11. Legajo 54, Documentos 282-283.

Alonso Guillén de la Carrera, del Consejo de Italia, viene de Nápoles y trae consigo: "un baso de unicornio [...] seis quadritos [...] otros dos quadritos [...] dos quadros de çera [...] seis quadros grandes, seis pequeños [...] un christo de plata en una cruz de ebano [...] quatro tapices de Flandes".

42) 1639, Julio, 29. Documento 284.

El príncipe de Butera, que vuelve a Italia, lleva consigo: "una tapiceria usada".

43) 1640, Marzo, 25. Legajo 55, Documentos 126-127.

El marqués de Leganés envía para el servicio del rey: "Quatro frontales para los quatro altares laterales. Frontal grande para el altar mayor [...] Seis Manipulos con Dos golas. Stolas cinco y una dellas con su flueco para el subdiacono. Un paño para el Lecturin con su labor y franja como la del Pulpitto [...]. Capa de coro con su capilla bordada y guarneçida de franga de oro [...]. Casullas quatro con sus cintas. Dos dalmaticas con sus fluecos para diacono y subdiacono [...]. Dosel sobre plata bordado de figuras de Relieve a oro de cañutillo con su zenefa con 43 fluecos de oro y su cordon de media seda carmessi. Cavecera de la cama de ocho columnas y sus

${ }^{41} \mathrm{Y}$ entre los que seguramente contaría el de Francesco I de Este obrado por Velázquez (hoy en la Galería Estense): S. SALORT, Op. cit., pp. 195-199. 
vasos de fondo de anbas partes de lama de plata quatro corniçes de plata para poner de guarniçión por defuera arriva de la cama con quatro ojas de plata que se han de poner a los lados adonde se juntan las mismas cornices llaves y ferramento que entra en armar la dicha cama [...] 7 Pedaços de zenefa bordados arrehines de cañutillo y Ramilletes de flores y pajaros para poner dentro y fuera de la dicha cama con una punta de franja echa de cañutillo de oro. Un Pedaço grande mayor de la dicha çenefa y de la misma lavor y sirve por Rodapies de tres partes de la cama y se queda haçiendo la otra parte para ponerse a la cavecera quando sirviere apartada de la pared. Otro pedaço de la dicha zenefa de tela de primavera con la misma punta que se pone en la cavecera de la cama que se arrima a la pared y se queda haçiendo el pedaço como los otros siete que se enviara con otra ocasion. 4 pedaços bordados de la misma Riqueza de la zenefa que sirven de margas a las quatro colunas cubierta çielo y siete cortinas de tabi de platta bordados de flores punto a la cantona que es lo mismo por el haz que por el enves excelente lavor y lindo dibujo. Un doçelillo de agua bendita de cristal de Roca con Reliquia de la carne de san carlos Borromeo. Dos sobremesas del mismo tabi y labor de la cama con sus zenefas alrrededor de la misma riqueça que son las de la cama [...]. Cubierta de la sillita de recamara y la del orinal de tela bordada y el orinal de platta. Dos almoadas grandes de la misma tela bordadas con sus fluecos de cañutillo de oro. Quatro basos que sirven de mançanillas a la cama bordadas de grande maestria [...]. Quatro colunas con sus pies para la cama cubiertas de lama de plata, todas llanas sin lavor ninguna con quatro travesañas aforradas por dentro y fuera de la misma lama de platta [...]. Dos sillas bordadas ricamente conforme a la cama de nogal ondeado con clavaçon toda de plata con franja grande de cañutillo. Dos Banquillos de campana de la misma bordadura y frangas de cañutillo con clavaçon de platta [...]. Una sillita para el principe del mismo bordado y nogal con clavaçon de Platta. La siguieta con su cantaro de Plata para la Recamara".

44) 1640, Mayo, 8. Documento 129.

Cosas que envía la archiduquesa Claudia para la familia real: "un relox grande con varias invenziones conforme la memoria que va en la caxa del mismo relox. Otro relox en forma de cruz [...]. Un aparador de plata para muñecas [...]. Un quadro de marfil y otros diferentes. Otros dos pequeños de çera. Unas vitelas y otras imagines [...]. En la terzera caxa [...] un tocador de plata para Su Majestad y quiza abran añadido unos libros de mapa y otras cosas que yo les deje".

45) 1640, Julio, 6-11. Legajo 53/3, Documentos 105-106.

Gabriele Riccardi, embajador del gran duque de la Toscana, que retorna a Florencia: "De cosas nuevas [...] Un Niño Jesús, un san Juan, dos hechuras de Crucifixo y unos Angeles todo de madera y chicos, 4 leoncillos de carton dorados y otras niñerias de altares todo de valor de sessenta ducados. Quatro Retraticos de santos y ocho mapas de partes [...]. De cosas usadas [...] Ocho quadros de retratos y dos de Santos. Un Relicario de bronce chiquito".

46) 1640, Julio, 6. Documentos 107-108.

Octavio Pucci, que viene por embajador de Florencia: “Treinta y nueve quadros de retratos y de santos y de otras Pinturas. Cassi todos son chicos y son copias. Un Espejo grande de Veneçia y otro chico. Ducientos y cinquenta vidrios de Veneçia".

47) 1642, Julio, 26. Legajo 54, Documentos 291-293.

Alonso de Cardona, gentilhombre de la boca del rey y primer caballerizo de don Juan de Austria, informa que "haviendo buelto de aquel Reyno [de Mallorca] ha dejado en Valencia las [cosas] que le quedaron sin poder vender en la almoneda [...] y supplica a Vuestra Majestad se sirva haçerle merced de que pueda bolver a pasarla a estos Reynos [...] pues no tiene plata ni joya alguna sino ropa usada y pinturas". 
48) 1642, Octubre, 25-Noviembre, 7. Documentos 294-295.

El duque de Montalto, que viene de Italia a servir en la jornada de Aragón, trae con su ropa: "En otro cajon de no 5 biene una estatua de bronce. En otro cajon de no 6 biene otra estatua de bronce. En otros tres cajones de $n^{\circ} 7,8$ y 9 bienen unos pedestales de marmol para las estatuas [...]. Mas en otro cajon de $\mathrm{n}^{\mathrm{o}} 15$ bienen dibersas pinturas. Mas en otro cajon de $n^{\mathrm{o}} 16$ bienen ocho cabezas de bronce de emperadores. Mas en otro cajon de $\mathrm{n}^{\mathrm{o}} 17$ biene una estatua de marmol. Mas en otro cajon de $\mathrm{n}^{\mathrm{o}} 18$ bienen doze quadros. Mas en otro cajon de $\mathrm{n}^{\mathrm{o}} 19$ biene otra estatua de bronce".

49) 1643, Junio, 9. Legajo 55, Documento 136.

El rey ordena que parta "Alonso Carbonel maestro mayor de las reales obras a disponer el aposento a la ciudad de Taracona y las demas partes que se le mandare".

50) 1643, Septiembre, 19. Legajo 53/3, Documento 117 y Legajo 54, Documento 300.

El conde de Siruela trae consigo de Italia: "cinco tapizerias de seda y lana".

51) 1643, Diciembre, 5. Legajo 55, Documento 139 .

"Pedro de Torres mi Aposentador de Palacio va a hacer mi aposento en los lugares por donde he de hacer mi jornada a Madrid".

52) 1644, Octubre, 5-19. Documento 142.

Pasaporte para diez cajas de pinturas "que ha traido a Çaragoza Francisco de Benavides de la compañía de JHS que las siete las encomendó en Napoles el Almirante de Castilla y las tres en Valencia el Duque de Arcos y las unas y las otras traen diferentes cosas [más adelante se especifica el contenido: pinturas] para mi servicio".

53) 1644, Noviembre, 5. Documento 143.

"Haviendo entendido Su Majestad que un cajon largo de pinturas que venia con su ropa desde Çaragoza se quedo en Cariñena por haverse quebrado el carro en que salio de aquella ciudad ha mandado que vaya uno de su caballeriza y se traiga en el, y porque no haya embarazo en la entrega [...] se despacha al señor don Fernando Ruiz de Contreras disponga que Miguel Martinez mesonero que es la persona en cuyo poder esta el cajon le entregue a la que llevare a su cargo el carro sin ninguna detencion".

54) 1645, Febrero, 22. Documentos 144145.

"Pedro de Torres Aposentador de Palacio y mi Ayuda de camara va a hazerme el aposento en esta Jornada de Aragon y [... en] mi servicio lleva los carros coches y mulas contenidas en la memoria inclusa [en la que se refieren catorce carros cargados de cossas de tapicería y furriera]".

55) 1645, Octubre, 12. Documento 146.

El marqués de Matonte, que viene de Italia, trae de regalo para el rey y sus hijos: "dos escritorios y dos bufetes conformes y unas Imágenes de cristal".

56) 1657, Octubre, 29-Diciembre, 4. Legajo 53/3, Documentos 129-134.

El duque de Terranova trae consigo de Italia: "Unos carros con unos porfidos [los tableros para los bufetes del Salón de los Espejos y doce bustos de emperadores] para Vuestra Majestad y que por ser alaxas que no pueden padecer infecçion, y estar ya lavadas y perfumadas por los ministros de Barcelona con summo cuydado se detendrán en Caragoza hasta que Vuestra Majestad resuelva lo que mas fuere servido assi en esto como en la ropa que queda de sus criados".

57) 1658, Enero, 26. Legajo 58, Documento 99.

El obispo emérito de Marsico "refiere que ha venido de Roma, y trahe algunos quadros grandes, y pequeños para Vuestra Majestad y la reina nuestra señora de orden del Principe Ludovisio, y que están en Barcelona junto con la ropa del Duque de Terranova, donde los han limpiado con toda diligencia [...] y que siendo assi, que vienen para Vues- 
tra Majestad estos quadros, se sirva Vuestra Majestad de mandar firmar los despachos inclusos para Cataluña y Aragon".

58) 1658, Julio, 15. Legajo 53/3, Documentos 136-139.

Camillo Massimo, nuncio de Alejandro VII, que retorna a Roma: "Ocho tapizes de Jardines viejos. Dos Laminas pintadas [...]. Piedras Belzuares Orientales pequeñas $\mathrm{n} .{ }^{\mathrm{o}}$ 40. Orientales entre grandes y pequeñas n. ${ }^{\circ}$ $80^{\prime \prime}$.

59) 1659, Septiembre, 12. Legajo 55, Documento 169.

Don Pedro de Gregorio envía desde Sicilia una alfombra "para servicio del culto divino en el Convento Real de las Descalzas".

60) 1665, Julio, 14. Documento 206.

“Desde Napoles con las galeras de la esquadra de aquel Reyno vienen dos cajas de Pinturas para mi servicio, que ha de recivir en Barcelona el capitán Jacome Antonio Gazanco, y encaminarlas a esta Corte a manos de Don Luis de oianguren".

61) 1673, Enero, 14. Documento 247.

El marqués de Astorga, virrey de Nápoles, informa que "en los Bageles que han de transportar a Barzelona la Infanteria que ha levantado en aquel Reyno, remite dichas Cajas con las vidrieras, colores, y otros géneros, que se le mandó embiasse para el Palacio y real sitio de Aranjuez".

62) 1687, Enero, 28-Febrero, 1. Documentos 279-280.

Los hijos del palatino de Rusia llevan consigo: "Un retrato del elector de Bramdemburg, de oro y diamantes".

63) 1689, Septiembre, 18. Documento 304.

El rey ordena que "los cajones que vienen de Napoles con las libreas para mi casamiento se traygan a esta Corte sin que se detengan ni abran en las Aduanas".
64) 1689, Septiembre, 28. Documentos 306-307.

El marqués de Villena, general de la caballería, lleva consigo a Barcelona para adorno de su casa: "Una tapiçeria de Bruxelas de figuras grandes que se conpone de nueve paños [...]. Otra tapiçeria de Boscajería con diez tapiçes [...]. Otra tapiçeria con nuebe tapiçes figuras grandes y boscajeria [...]. Otra tapiçeria con doçe tapiçes los ocho de Galerias y los quatro de figuras [...]. Nuebe laminas de diferentes tamaños y entre ellas una grande de [¿ágata?] guarnecida el marco de plata. Dos pinturas de dos santos christos [...]. Cinco laminas diferentes que ban entre la colgadura [...]. Tres laminas diferentes".

65) 1690, Agosto, 7. Documentos 319321.

El conde Sciarra Luigi Tarasconi, enviado extraordinario del duque de Parma, remite a Italia: "quinze pinturas biejas, seis grandes y nuebe pequeñas".

66) 1693, Octubre, 20. Documentos 374375.

El conde Carlo Rasini, que marcha a Milán a servir el cargo con que Su Majestad le ha servido honrar, lleva consigo: "dos pinturas, una de Tintoreto y otra de Venezia".

67) Sin datar (¿1696?). Legajo 54, Documento 352.

Entre la ropa que lleva el conde de Melgar: "otros tres cajones en que ban pinturas y unas ymajenes de bulto".

68) 1699, Abril, 25. Documentos 373-375.

El conde de Berlips, enviado extraordinario a la corte de Viena, lleva consigo: "dos joyas con el retrato del Rey".

69) 1700, Abril, 15-20. Documentos 393396.

Francisco de Moles, duque de Parete, que va a servir la embajada de Alemania, lleva consigo: "un san Joseph de Napoles usado. Mas un Nacimiento usado. Mas una santa Cathalina usada. Mas un escaparate usado con reliquias de san Prospero Martir [...]. 
Unas pinturas usadas. Una estatua del beato Felix, de barro, con una urna usada [...]. Dos quadros con sus marcos usados [...]. Quatro Paños de tapizes usados. Nuebe Paños de tapizes usados. Otro paño de tapiz usado. Siete lienços pintados viexos [...]. Una pinturilla usada [...]. Una pintura de san Francisco con su marco de concha usado. Otra pintura de Nuestra Señora con su marco de lo propio".

\section{BIBLIOGRAFÍA}

ALVAR EZQUERRA, A., "Los intercambios culturales entre los Países Bajos y Castilla en tiempos de Felipe II. Un muestreo de las cédulas de paso", Indagación. Revista de Historia y Arte, 2, 1991, pp. 91-110.

AZCÁRATE, J. M., "Anales de la construcción del Buen Retiro", Anales del Instituto de Estudios Madrileños, 1, 1996, pp. 99-135.

BENITO GARCÍA, P., “El Alcázar vestido de seda", en F. CHECA CREMADES (ed.), El Real Alcázar de Madrid, Madrid, 1994, pp. 308-317.

BROWN, J. y ELLIOT, J. H., Un palacio para el rey, Madrid, 2003.

CANELLAS, A., "Instituciones aragonesas de antaño. La Diputación del Reino", Cuadernos de Historia Jerónimo Zurita, 3334, 1979, pp. 7-30.

CARO DE MALLÉN, A., Contexto de las reales fiestas que se hizieron en el Palacio del Bven Retiro, Madrid, 1637.

ELLIOT, J. H. y DE LA PEÑA, J. F., Memoriales y cartas del conde duque de Olivares, Vol. II, Madrid, 1981.

FERNÁNDEZ BAYTON, G., Inventarios Reales. Testamentaría del rey Carlos II. 17011703, Vol. I, Madrid, 1975.

GARCÍA CUETO, D., “Don Diego de Aragón, IV Duque de Terranova, y el envío de esculturas para Felipe IV durante su embajada en Roma (1654-1657)", Archivo Español de Arte, 311, 2005, pp. 317322.

GARCÍA GARCÍA, B. J., "Los regalos de Isa- bel Clara Eugenia y la Corte española. Intimidad, gusto y devoción", Reales Sitios, 143, 2000, pp. 16-27.

"El legado de arte y objetos suntuarios de las testamentarías de Isabel Clara Eugenia y el Cardenal Infante (1634-1645)", en J. L. COLOMER (ed.), Arte y diplomacia de la monarquía hispánica en el siglo XVII, Madrid, 2003, pp. 134-159.

"Regalos diplomáticos y bienes suntuarios en la corte española (1580-1665)", en E. GARCÍA SANTO-TOMÁS (ed.), Materia crítica: Formas de ocio y de consumo en la cultura áurea, Madrid-Frankfurt, 2009, pp. 213-249.

GASCÓN DE TORQUEMADA, G., Gaçeta y nuevas de la Corte de España desde el año 1600 en adelante, Madrid, 1991.

GIL SAURA, Y., "Jaspes de Tortosa para el Palacio del Buen Retiro de Madrid", Anuario del Departamento de Historia y Teoría del Arte, 19, 2007, pp. 67-78.

GOLDBERG, E., "Artistic relations between the Medici and the Spanish courts, 1587-1621: Part I \& II", The Burlington Magazine, 1115 y 1121, 1996, pp. 105-114 y 529-540.

"State gifts from the Medici to the court of Philip III: The Relazione segreta of Orazio della Rena", en J. L. COLOMER (ed.), Arte y diplomacia de la monarquía hispánica en el siglo XVII, Madrid, 2003, pp. 114-133.

JORDAN, A., "Mujeres mecenas de la casa de Austria y la infanta Isabel Clara Eugenia", en El arte en la corte de los Archiduques Alberto de Austria e Isabel Clara Eugenia (1598-1633). Un reino imaginado, Madrid, 1999, pp. 118-137.

LÓPEZ CONDE, R., “Las relaciones artísticas entre el príncipe Ludovisi y la monarquía española. Nuevos datos y evidencias" [en vías de publicación].

LÓPEZ Y MALTA, C., Historia descriptiva del Real Sitio de Aranjuez, Madrid, 1868. 
MARQUÉS DE LOZOYA, "Algunas pérdidas del Patrimonio Nacional y de los patronatos reales en los años de 1936-1939", Archivo Español de Arte, 138, 1962, pp. 8994.

MORÁN TURINA, J. M., "Importaciones y exportaciones de pinturas en el siglo XVII a través de los registros de los libros de pasos", en Madrid en el contexto de lo hispánico desde la época de los descubrimientos. Actas del Congreso nacional, Madrid, 1994, pp. 543-562.

MORÁN TURINA, J. M. y RUDOLF, K., "Nuevos documentos en torno a Velázquez y a las colecciones reales", Archivo Español de Arte, 259-260, 1992, pp. 289302.

PÉREZ DE TUDELA, A. y JORDAN, A., "Luxury Goods for Royal Collectors: exotica, princely gifts and rare animals exchanged between the Iberian Courts and Central Europe in the Renaissance (15601612)", Jahrbuch des Kunsthistorischen Museums Wien, 3, 2001, pp. 1-127.
REAL ACADEMIA DE LA HISTORIA, Memorial Histórico Español, Tomo XIII, Madrid, 1861.

Memorial Histórico Español, Tomo XIV, Madrid, 1862.

SALORT, S., Velázquez en Italia, Madrid, 2002.

SESMA, J. A., “Las Generalidades del Reino de Aragón: su organización a mediados del siglo XV", Anuario de historia del derecho español, 46, 1976, pp. 393-468.

TORRÁS, S., Pintura catalana del barroc. L'auge collleccionista i l'ofici de pintor al segle XVII, Barcelona, 2012.

UHAGÓN, F. R., "El Santo Cristo de María Stuart", Revista de Archivos, Bibliotecas y Museos, Año V, 1901, pp. 1-10 y 102-125.

VERGANI, G. A., "La decorazione delle sale del piano terra", en G. A. VERGANI (ed.), Il palazzo dei conti Rasini a Cavenago di Brianza, Cavenago di Brianza, 1997, pp. 89-125. 